\title{
Gambaran Kecemasan Orangtua yang hanya Memiliki Anak Perempuan di Kabupaten Tabanan, Bali
}

\author{
Kadek Ayu Monika dan David Hizkia Tobing \\ Program Studi Psikologi, Fakultas Kedokteran, Universitas Udayana \\ kadekayumonika88@gmail.com
}

\begin{abstract}
Abstrak
Indonesia mengenal tiga sistem kekerabatan dalam memperoleh garis keturunan, yaitu sistem kekerabatan patrilineal, sistem kekerabatan matrilineal dan sistem kekerabatan parental (Sukerti, 2012). Bali merupakan salah satu daerah yang menganut sistem kekerabatan patrilineal, dimana kekerabatan ini ditentukan bahwa garis keturunan hanya dilihat dari garis laki-laki, oleh karena itu konsekuensinya ahli waris hanyalah anak laki-laki (Sukerti, 2012). Hal tersebut berarti bahwa memiliki anak laki-laki adalah sebuah keharusan bagi masyarakatnya untuk tetap meneruskan garis keturunan, dan akan menjadi sebuah masalah bagi individu yang tidak memiliki anak laki-laki, hal tersebut terkait dengan mencari penerus garis keturunan, takut akan kehilangan anak, dan kekhawatiran tidak ada yang akan bertanggung jawab dengan kehidupan orangtua ketika tua (Monika, 2016). Begitupula yang terjadi pada orangtua di Bali khususnya daerah Tabanan, salah satu kabupaten yang terbilang fleksibel atau terbuka, dibandingkan dengan kabupaten lainnya yang ada di Bali terkait dengan hukum keluarga, khususnya perkawinan, menganggap bahwa dengan hanya memiliki anak perempuan itu berarti tidak dapat meneruskan garis keturunannya. Masyarakat yang tidak dapat meneruskan keturunannya tentu akan merasa cemas akan posisi tersebut. Kecemasan (anxiety) menurut Freud (dalam Feist \& Feist, 2013) menjelaskan bahwa merupakan situasi afektif yang dirasa tidak menyenangkan yang diikuti oleh sensasi fisik yang memperingatkan seseorang akan bahaya yang mengancam. Berdasarkan hal tersebut, penelitian ini difokuskan untuk membahas mengenai gambaran kecemasan orangtua yang hanya memiliki anak perempuan di daerah Tabanan, Bali. Penelitian ini menggunakan metode kualitatif dengan desain penelitian fenomenologi. Pengambilan data dilakukan dengan menggunakan teknik wawancara dan observasi pada tujuh orang responden dan wawancara pada tujuh orang significant others. Hasil penelitian ini menunjukkan bahwa gambaran kecemasan orangtua yang hanya memiliki anak perempuan terdiri dari perasaan orangtua, bentuk kecemasan, faktor yang memicu dan menurunkan kecemasan, serta upaya yang dilakukan orangtua yang hanya memiliki anak perempuan.
\end{abstract}

Kata kunci: kecemasan, orangtua, anak perempuan

\begin{abstract}
Indonesia has three kinds of kinship system in obtaining lineage, which are patrilineal, matrilineal and parental kinship system (Sukerti, 2012). Bali is one of the areas that embraces the patrilineal kinship system, where the kinship is determined that the lineage is only seen from the male line, hence all heirs should be boys (Sukerti, 2012). Having a son becomes a necessity for those people to continue the lineage, and will be a problem if they don't, associated with finding a lineage, fear of losing child and worrying about old age (Monika,2016). Similarly, it happens to parents in Bali, especially in Tabanan district, one of the most flexible compared to other district in Bali, related to family law, especially marriage, it is assumed that by only having daughters, can't continue their lineage. People who can't continue their lineage will feel anxious about the position. Anxiety according to Freud is (in Feist \& Feist, 2013) described as an unpleasant affective situation followed by a physical sensation that warns a person of a threatening danger. Based on the circumstances, this study focused on the anxiety level of parents who only have daughters in the district of Tabanan, Bali. This research uses qualitative method with phenomenology research design. The data was collected through interviews and observation technique on seven respondents and seven significant others interview. The results of this study shows the overview. Overview of anxiety level, overview of anxiety level among parents, parents emotional state, anxiety levels as well as efforts made by parents who only have daughter.
\end{abstract}

Keywords: anxiety, parent, daughter 


\section{LATAR BELAKANG}

Manusia adalah makhluk sosial yang saling membutuhkan satu sama lain. Manusia melakukan interaksi sosial dalam lingkungan tempatnya berada, baik hubungan antarindividu, hubungan individu dengan kelompok ataupun kelompok dengan kelompok. Interaksi sosial dapat menciptakan kebersamaan manusia dalam masyarakat tempat individu tinggal. Interaksi sebagai wadah manusia untuk saling berkomunikasi atau saling memengaruhi antar sesama yang dapat berlangsung sepanjang hidupnya di dalam masyarakat. Dapat dikatakan bahwa interaksi sosial merupakan dasar proses sosial, yang menunjuk pada hubungan-hubungan sosial yang dinamis. Mengingat manusia sebagai makhluk sosial dan melalui adanya interaksi antar sesama, maka secara alamiah manusia memiliki dorongan untuk mempertahankan keadaannya dalam masyarakat. Umumnya manusia akan mencari pasangan guna melakukan hubungan timbal balik. Tidak hanya itu, manusia berpasangan sebagai bentuk evolusi yang nantinya akan berpengaruh dalam masyarakat tempat individu berada (Soekanto, 2005).

Manusia mencari pasangan yaitu untuk meneruskan garis keturunan. Agama Hindu memandang bahwa, tujuan dari perkawinan yaitu selain membentuk keluarga yang bahagia dan kekal, juga untuk mendapatkan keturunan, meneruskan tanggung jawab orangtua dan leluhurnya (Windia, et al., 2014). Penting bagi manusia untuk mempertahankan garis keturunan dalam masyarakat. Adanya keturunan atau penerus keluarga, status atau kedudukan yang melekat dalam diri manusia di masyarakat dapat diteruskan dan bertahan. Muncul beberapa sistem kekerabatan sebagai upaya mempertahankan garis keturunan dalam masyarakat.

Indonesia mengenal tiga sistem kekerabatan dalam garis keturunan, yaitu sistem kekerabatan patrilineal, sistem kekerabatan matrilineal dan sistem kekerabatan parental (Sukerti, 2012). Menurut sistem patrilineal kedudukan suami lebih utama dari kedudukan pihak istri, contohnya pada masyarakat Sumatera Selatan, Tapanuli serta Bugis. Sistem patrilineal berkebalikan dengan sistem matrilineal, dalam sistem matrilineal dijelaskan bahwa kedudukan pihak istri lebih utama dibandingkan kedudukan pihak laki-laki, contohnya pada masyarakat Minangkabau. Pada sistem parental, kedudukan suami dan istri berimbang sehingga bersama-sama mengurus segala kebutuhan keluarga seperti kebutuhan sehari-hari, masa depan dan pendidikan anak. Sistem parental biasanya diterapkan oleh masyarakat Jawa, Madura dan Sunda (Muhammad, 2000).

Umumnya, diketahui bahwa di Indonesia lebih banyak yang menganut sistem kekerabatan patrilineal. Garis keturunan pada sistem kekerabatan patrilineal mengikuti pihak laki-laki. Masyarakat yang percaya akan sistem adat patrilineal, kedudukan anak laki-laki lebih besar pengaruhnya karena dipercaya sebagai penerus keluarga yang menjadi ahli waris (Sukerti, 2012).

Bali merupakan salah satu daerah yang menganut sistem kekerabatan patrilineal, kekerabatan ini ditentukan bahwa garis keturunan hanya dilihat dari garis laki-laki, sehingga hanya anak laki-laki yang dapat menjadi ahli waris (Sukerti,
2012). Sesuai dengan sistem kekerabatan patrilineal, adanya keturunan laki-laki dalam keluarga sangat penting. Hal ini terkait dengan tanggung jawab yang harus diteruskan, baik berupa kewajiban (swadharma) dan hak-hak (swadikara) seseorang dalam keluarga dan masyarakat (desa pekraman/banjar). Kewajiban yang harus diteruskan meliputi kewajiban berkaitan dengan aktivitas keagamaan sesuai dengan ajaran agama Hindu dan tempat suci (parahyangan), baik dalam keluarga maupun masyarakat, kewajiban yang berkaitan dengan aktivitas kemanusiaan (pawongan) dan kewajiban yang berkaitan dengan aktivitas memelihara lingkungan alam (palemahan), baik untuk kepentingan keluarga maupun masyarakat (Windia, et al., 2014).

Hak-hak (swadikara) seseorang dalam keluarga dan masyarakat ada hubungan dengan penerusan harta kekayaan keluarga dan leluhur serta pemanfaatan fasilitas milik desa adat pekraman, seperti tanah desa, tempat suci dan kuburan (setra). Harta kekayaan keluarga dapat dikelompokkan menjadi tiga, yaitu harta tetamian (warisan leluhur atau dikenal pula dengan istilah harta pusaka), harta gunakaya (harta bersama yang didapat selama perkawinan) dan harta tetadtadan (harta bawaan yang diperoleh sebelum perkawinan, baik berupa hasil karya sendiri/ sekaya maupun berupa pemberian/ jiwadana) (Windia, et al., 2014).

Keberadaan anak perempuan masih dinomor duakan, karena melihat garis keturunan yang ditentukan oleh anak laki-laki. Hal ini dapat dilihat pada kalangan masyarakat khususnya pasangan suami istri yang akan memiliki anak, melakukan program kehamilan agar dapat memiliki anak laki-laki. Hal tersebut menunjukkan bahwa suatu keharusan bagi umat Hindu di Bali memiliki anak laki-laki untuk tetap meneruskan garis keturunan. Individu secara aktif melakukan reproduksi untuk dapat memiliki anak laki-laki, namun semenjak kemunculan KB (keluarga berencana), masyarakat Bali mulai meninggalkan kebiasaan tersebut. Keluarga berencana (KB) merupakan salah satu program dari pemerintah untuk menekan laju pertumbuhan penduduk di Indonesia dengan hanya memiliki maksimal 2 orang anak. Pengertian keluarga berencana adalah suatu usaha yang mengatur banyaknya jumlah kelahiran sehingga tidak menimbulkan kerugian bagi ibu, bayi, keluarga dan masyarakat sebagai akibat langsung dari kelahiran. Program keluarga berencana di Indonesia pertama kali dicetuskan oleh organisasi swasta, kemudian tanggung jawab terhadap program keluarga berencana diambil alih oleh Badan Koordinasi Keluarga Berencana Nasional (BKKBN). BKKBN didirikan dibawah tanggung jawab Presiden Republik Indonesia pada tanggal 22 Januari 1970. Berhasilnya perkembangan ekonomi bersama-sama dengan pertumbuhan penduduk pasti akan membawa kesejahteraan dan perbaikan kehidupan bangsa dengan lebih cepat dikarenakan biaya yang ditanggung tiap keluarga dapat diminimalisir (Teknik Keluarga Berencana, 1980).

Kemunculan KB tentu saja membatasi orangtua dalam memperoleh seorang anak yaitu maksimal 2 orang anak, namun tidak semua orangtua dapat melahirkan anak laki-laki, masih banyak orangtua yang hanya dikaruniai anak perempuan. Hal tersebut menimbulkan masalah di masyarakat. keluarga yang tidak memiliki anak laki-laki tidak dapat memiliki garis keturunan yang berdampak pada 
keberlangsungan kedudukan keluarga yang bersangkutan dalam masyarakat. konsekuensi dari hal tersebut adalah musnahnya keturunan dari keluarga yang tidak memiliki anak laki-laki (Atmaja, 2008).

Masyarakat yang tidak dapat meneruskan keturunannya tentu akan memunculkan rasa takut di dalam posisi tersebut, hal tersebut dikarenakan munculnya rasa cemas pada orangtua terkait alasan mencari penerus garis keturunan, ketakutan akan kehilangan anak, dan khawatir tidak akan ada yang akan bertanggung jawab dengan kehidupan orangtua ketika lanjut usia (Monika, 2016). Kecemasan (anxiety) menurut Freud (di dalam Feist \& Feist, 2013) merupakan situasi afektif yang dirasa tidak menyenangkan yang diikuti oleh sensasi fisik yang memperingatkan seseorang akan bahaya yang mengancam. Muncul beberapa solusi yang dapat dilakukan untuk meringankan kecemasan individu yang hanya memiliki anak perempuan di Bali. Masyarakat yang hanya memiliki anak perempuan dapat memilih melaksanakan tradisi nyentana atau Pada gelahang untuk meneruskan garis keturunannya. Nyentana merupakan sebuah tradisi pengantin laki-laki akan tinggal di rumah perempuan dan melaksanakan kewajibannya dirumah pihak wanita (Atmaja, 2008).

Pada gelahang menjadi alternatif perkawinan selain nyentana, agar keluarga tetap dapat meneruskan keturunan (Pursika \& Arini, 2012). Jumlah pasangan yang diduga memilih perkawinan Pada gelahang diperkirakan akan semakin meningkat disebabkan oleh beberapa hal. Pertama, berkembangnya pendidikan dan kesadaran akan hak-hak asasi manusia terutama dalam kesetaraan antara kaum laki-laki dan perempuan. Kedua, tumbuhnya kesadaran akan pentingnya kualitas keluarga dibandingkan kuantitasnya, sehingga semakin banyak keluarga yang menjalankan program keluarga berencana $(\mathrm{KB})$ dalam arti membatasi jumlah kelahiran demi menjaga kualitas keluarga (Windia, et al., 2009).

Persyaratan perkawinan Pada gelahang tidak jauh berbeda dengan perkawinan biasa. Perbedaan antara perkawinan Pada gelahang dengan perkawinan biasa terdapat dalam pasobayan mawarang atau perjanjian antara pengantin dan kedua keluarga mengenai bentuk perkawinan serta konsekuensi tanggung jawab dari bentuk perkawinan tersebut. Tanggung jawab yang dilaksanakan oleh suami istri yang menjalankan perkawinan Pada gelahang harus seimbang terhadap keluarga dan masyarakat masing-masing, baik secara kenyataan (sekala) atau spiritual (niskala), karena suami dan istri berstatus purusa (Dyatmikawati, 2011).

Tradisi-tradisi tersebut dijadikan sebagai solusi bagi masyarakat Bali yang hanya memiliki anak perempuan, terlebih lagi di kabupaten Tabanan. Daerah yang terkenal dengan sistem agrarisnya ini sudah tidak asing akan istilahistilah tersebut. Berhubungan dengan hukum keluarga, khususnya perkawinan, pemikiran masyarakat yang berada di Kabupaten Tabanan relatif lebih fleksibel atau terbuka dibandingkan dengan kabupaten lainnya yang ada di Bali. Salah satu contoh yaitu perkawinan nyentana. Di tempat lain di Bali sulit di temukan keluarga yang telah dikaruniai anak laki-laki, melangsungkan perkawinan nyentana bagi anak perempuannya, tetapi di Kabupaten Tabanan tradisi tersebut masih bisa terjadi (Windia, et al., 2014). Sebagian besar masyarakat melakukan tradisi nyentana untuk meneruskan keturunan, namun solusi ini tidaklah selalu berjalan dengan baik.

Banyak masyarakat Bali yang keliru atau menyalah artikan istilah nyentana, individu memandang bahwa laki-laki yang pada umumnya sebagai kepala rumah tangga akan digantikan perannya oleh perempuan ketika individu nyentana. Hal tersebut mengakibatkan banyak masyarakat Bali khususnya kaum laki-laki enggan untuk nyentana. Mencari sentana (lakilaki yang akan nyentana) terbilang sulit, dikarenakan kekeliruan dalam mengartikan istilah nyentana. Hal tersebut menjadi masalah baru bagi masyarakat yang hanya memiliki anak perempuan di Bali, khususnya di Tabanan (Atmaja, 2008).

Orangtua akan merasa cemas jika anak perempuannya tidak dapat mencari sentana, sehingga banyak orangtua yang melarang anaknya untuk berpacaran dengan sembarangan laki-laki, terutama jika tidak dapat nyentana. Nyentana dapat menjadi solusi sekaligus menjadi masalah bagi individu. Berdasarkan hasil studi pendahuluan terhadap salah satu tokoh adat di Tabanan, diketahui bahwa beberapa keluarga yang hanya memiliki anak perempuan di desanya sempat mengalami masalah yang serius, anak tersebut memilih untuk kawin lari, agar tidak diminta untuk mencari sentana. Tidak hanya itu, adapula salah satu keluarga di desanya yang hanya memiliki anak perempuan berhasil untuk melakukan perkawinan nyentana, namun pada akhirnya anak tersebut memilih untuk bercerai dan tidak lama kemudian memutuskan untuk menikah meninggalkan orangtuanya (Monika, 2016).

Masalah-masalah yang muncul dari tradisi nyentana ini tentunya menimbulkan kecemasan yang berbeda-beda bagi orangtua. Kecemasan juga dapat diartikan sebagai gangguan psikologis, meliputi ketegangan motorik (bergetar, tidak mampu duduk tenang, tidak mampu bersantai); hiperaktivitas (pusing, jantung yang berdetak cepat dan berkeringat); serta harapan-harapan yang dirasakan dan pikiran mendalam yang dialami oleh individu (King, 2010). Terbukti dari hasil survei pada 10 orangtua yang hanya memiliki anak perempuan di kabupaten Tabanan, 8 diantaranya mengaku merasa cemas jika hanya memiliki anak perempuan jika dikaitkan dengan sistem perkawinan di Bali. Hanya memiliki anak perempuan membuat orangtua memilih alternatif lain untuk dapat meneruskan garis keturunannya, yaitu melalui perkawinan nyentana, namun orangtua merasa cemas jika anak perempuannya tidak mendapatkan laki-laki yang mau untuk diajak di rumah atau nyentana. Hal tersebut menyebabkan munculnya kecemasan pada orangtua terkait alasan mencari penerus garis keturunan, takut akan kehilangan anak, dan kekhawatiran tidak ada yang akan bertanggung jawab dengan kehidupan orangtua ketika lanjut usia (Monika, 2016).

Tradisi perkawinan Pada gelahang juga memiliki beberapa kendala yaitu adanya selisih paham antar pewaris dan ahli waris tentang pembagian warisan, dan adanya kekaburan tentang pembagian harta warisan yang tidak bisa dibagi yaitu 
tanggung jawab anak dari para pelaku Pada gelahang (Nugraha, 2014). Tidak semua orangtua yang hanya memiliki anak perempuan memilih tradisi ini, dikarenakan tradisi nyentana dan Pada gelahang ini tidak dilaksanakan secara merata diseluruh Bali. Selain itu, pandangan dan lingkungan dari masing-masing keluarga dalam menilai anak laki-laki dan perempuan memengaruhi keputusan yang dipilih dalam meneruskan garis keturunan. Berdasarkan kasus-kasus yang telah diuraikan di atas, maka permasalahan dalam penelitian ini dapat dirumuskan dalam sebuah pertanyaan, yakni: Bagaimana gambaran kecemasan orangtua yang hanya memiliki anak perempuan di kabupaten Tabanan, Bali?

\section{METODE PENELITIAN}

Penelitian ini menggunakan metode penelitian kualitatif dengan pendekatan fenomenologi. Penelitian kualitatif adalah penelitian yang bertujuan untuk memahami fenomena tentang apa yang dialami oleh subjek penelitian seperti perilaku, persepsi, motivasi, dan lain-lain, secara holistik dan dengan cara deskripsi dalam bentuk kata-kata dan bahasa, pada suatu konteks khusus yang alamiah dan dengan memanfaatkan berbagai metode ilmiah (Moleong, 2014). Fenomenologi merupakan pendekatan kualitatif yang digunakan peneliti mengeksplorasi kehidupan nyata, kasus atau beragam kasus melalui pengumpulan data yang rinci dan mendalam yang melibatkan beragam sumber informasi, dan melaporkan deskripsi kasus dan tema kasus (Creswell, 2015).

Penelitian kualitatif dipilih dalam penelitian ini yaitu untuk memahami fenomena yang dialami orangtua yang hanya memiliki anak perempuan, dan melalui penelitian kualitatif akan dihasilkan data deskriptif berupa data-data tertulis atau lisan dari orang-orang yang menjadi fokus penelitian serta perilaku yang dapat diamati. Pendekatan fenomenologi didasarkan pada fenomena kecemasan yang dialami orangtua yang hanya memiliki anak perempuan, terkait dengan sistem perkawinan yang dianut di Bali. Berdasarkan fenomena tersebut, diperlukan data yang lebih rinci dan mendalam terkait dengan fenomena kecemasan orangtua khususnya mengenai gambaran kecemasan orangtua yang hanya memiliki anak perempuan di Kabupaten Tabanan.

\section{Karakteristik Responden}

Penelitian ini melibatkan tujuh orang responden, yaitu orangtua yang hanya memiliki anak perempuan dengan rentang usia remaja akhir dan belum menikah. Keenam responden berjenis kelamin laki-laki dan satu perempuan, terkait dengan kesediaan untuk diwawancara. Seluruh responden hanya memiliki anak perempuan dengan jumlah anak perempuan yang dimiliki berbeda-beda. Pekerjaan masing-masing responden berbeda-beda, responden satu dan lima memiliki pekerjaan dengan kategori yang sama, yaitu sebagai wiraswasta, responden dua sebagai dosen, responden tiga sebagai buruh bangunan, responden empat sebagai pemborong, responden enam sebagai TNI dan responden terakhir bekerja di salah satu kantor pemerintahan di daerah Tabanan sebagai PNS. Karakteristik ketujuh responden diatas akan dirangkum dalam tabel 1 (terlampir).

\section{Lokasi Pengumpulan Data}

Pengambilan data dalam penelitian ini, khususnya melibatkan tujuh responden yang berdomisili di Kabupaten Tabnan, Bali. karena menurut Windia et al. (2014) menyatakan bahwa dalam hubungan dengan hukum keluarga, khususnya perkawinan, masyarakat yang tinggal di Kabupaten Tabanan relatif lebih fleksibel atau terbuka dibandingkan dengan kabupaten lainnya yang ada di Bali. Seperti satu contoh, perkawinan nyentana. Ditempat lainnya di Bali, sulit ditemukan keluarga yang telah dikaruniai anak laki-laki, melangsungkan perkawinan nyentana bagi anak perempuannya, tetapi di Kabupaten Tabanan hal tersebut bisa terjadi.

\section{Teknik Pengumpulan Data}

Pengumpulan data dalam penelitian ini menggunakan teknik wawancara dan observasi. Pengumpulan data dengan wawancara diawali dengan menyusun guideline yang berisi garis-garis besar pertanyaan. Observasi dilakukan secara deskriptif selama wawancara berlangsung melalui pengamatan dan pencatatan terhadap respon nonverbal responden dalam menanggapi pertanyaan yang diajukan. Observasi yang dilakukan peneliti berlokasi di tempat dan hari yang sama dengan pelaksanaan wawancara. Hasil wawancara dibuat dalam bentuk verbatim, sedangkan hasil observasi dibuat dalam bentuk fieldnote.

\section{Teknik Analisa Data}

Penelitian ini menggunakan teknik analisis data dengan Model Miles and Huberman (dalam Sugiyono, 2014) yang terbagi atas tiga aktifitas, yaitu reduksi data, penyajian data, dan menarik kesimpulan atau verifikasi.

\section{Reduksi data}

Tahap pertama dalam reduksi data adalah dengan melakukan open coding. Hampir seluruh teks yang diperoleh dari verbatim maupun fieldnote ditandai, untuk kemudian dibuatkan kategori-kategori sesuai makna dan maksud dari teks tersebut. Tahap selanjutnya, hubungan dari kategorikategori teks yang telah disusun sebelumnya dilihat lalu dikumpulkan dengan kategori-kategori yang saling berkaitan. Tahap terakhir dalam reduksi data adalah selective coding, yaitu memilih kategori-kategori yang memiliki kaitan dan sesuai dengan fokus dalam penelitian.

Penyajian data

Setelah melakukan reduksi data, hal yang selanjutnya dilakukan adalah memilih cara untuk menyajikan data. Data dalam penelitian ini disajikan dalam bentuk tabel yang berisi hasil pengumpulan data dari kedua responden dan telah disusun sesuai dengan kategori-kategori yang saling berkaitan. Penarikan kesimpulan atau verifikasi

Penarikan kesimpulan kemudian dilakukan setelah menyelesaikan hasil penelitian dan pembahasan yang berupa narasi maupun yang disajikan dalam bentuk tabel-tabel.

\section{Kredibilitas Penelitian}

Terdapat beberapa macam cara pengujian kredibilitas data antara lain dilakukan dengan perpanjangan pengamatan, meningkatkan ketekunan, triangulasi data, analisa kasus negatif, dan menggunakan bahan referensi (Sugiyono, 2014). Teknik pengujian kredibilitas yang dipergunakan dalam 
penelitian ini adalah perpanjangan pengamatan, meningkatkan ketekunan dan teknik triangulasi data.

\section{Isu etika penelitian}

Berikut beberapa isu etik yang diperhatikan dalam penelitian ini berdasarkan pada kode etik Himpunan Psikologi Indonesia, (2010), seperti perlindungan responden penelitian dari konsekuensi yang tidak menyenangkan, baik dari keikutsertaan atau penarikan diri atau pengunduran dari keikutsertaan. Sebelum pengambilan data dilakukan, peneliti memberikan informed consent yang menjelaskan kepada calon responden tentang penelitian yang akan dilakukan, serta mengenai asas kesediaan sebagai responden penelitian yang bersifat sukarela, sehingga memungkinkan pengunduran diri atau penolakan untuk terlibat. Aspek kerahasiaan dapat menciptakan rasa kepercayaan dan keamanan pada diri responden. Ketika proses penelitian telah berakhir, hasil penelitian dapat diberikan kepada responden ataupun pihak institusi jika dibutuhkan.

\section{HASIL PENELITIAN}

Penelitian ini menggunakan pendekatan fenomenologi yang berarti hasil penelitian dibahas dengan unit analisis kelompok. Setelah peneliti menemukan pola kesamaan dan hubungan dari seluruh responden atas pertanyaan penelitian, kemudian dibuat dalam bentuk topik-topik utama yang berlaku pada seluruh responden yang berpartisipasi dalam penelitian ini yaitu orangtua yang hanya memiliki anak perempuan. Segala hal yang dituangkan dalam bagan hasil penelitian ini merupakan fakta hasil temuan dari proses pengumpulan data yang telah dianalisis. Adapun hasil penelitian ini dijelaskan berdasarkan empat kategori yaitu, emosi orangtua, bentuk kecemasan, faktor yang memengaruhi kecemasan, upaya yang dilakukan orangtua.

\section{Emosi Orangtua yang Hanya Memiliki Anak Perempuan}

(bagan 1. Emosi orangtua yang hanya memiliki anak perempuan. Terlampir) Emosi orangtua yang hanya memiliki anak perempuan bermacam-macam, dan kemudian dikategorikan kedalam dua kategori yaitu emosi positif dan emosi negatif. Emosi positif yang muncul ketika hanya memiliki anak perempuan seperti bahagia, menerima, bersyukur, santai, ikhlas dan pasrah, sedangkan emosi negatif yang muncul yaitu rasa kecewa, takut, lebih waspada, iri melihat orang lain, berpikir keras dan was-was.

\section{Bentuk Kecemasan Orangtua yang Hanya Memiliki Anak Perempuan}

(bagan 2. Bentuk kecemasan orangtua yang hanya memiliki anak perempuan. Terlampir) Emosi yang muncul akibat hanya memiliki anak perempuan tentu saja menimbulkan kecemasan, khususnya karena emosi negatif yang dimunculkan oleh responden. Tidak semua responden memunculkan bentuk kecemasan, hanya lima dari tujuh responden yang memunculkan bentuk kecemasan. Adapun bentuk kecemasan yang muncul seperti menangis, sulit tidur, sakit perut, melamun dan cepat marah.

\section{Faktor yang Memengaruhi Kecemasan Orangtua}

(Bagan 3. Faktor yang memengaruhi kecemasan orangtua. Terlampir) Terdapat beberapa faktor yang memengaruhi munculnya kecemasan pada orangtua yang hanya memiliki anak perempuan. Pada kali ini, faktor yang memengaruhi kecemasan orangtua dibagi dalam dua kategori yaitu, faktor yang meningkatkan kecemasan dan faktor yang menurunkan kecemasan orangtua.

Faktor yang memicu munculnya kecemasan

Orangtua yang hanya memiliki anak perempuan akan memiliki kendala terkait penerus garis keturunan, mengingat di Bali menganut sistem kekerabatan patrilineal garis keturunan jatuh pada anak laki-laki, sehingga orangtua yang hanya memiliki anak perempuan tentu akan berpikir mengenai garis keturunannya. Apabila tidak ada yang meneruskan garis keturunan, tentu saja keluarga akan menjadi putung (garis keturunan terputus). Hal tersebut juga memunculkan pikiran pada orangtua yang hanya memiliki anak perempuan mengenai masa dihari tuanya.

Bagi orangtua yang hanya memiliki anak perempuan, terdapat alternatif untuk meneruskan keturunan yaitu melalui perkawinan nyentana. Mendapatkan laki-laki yang mau nyentana sudah terbilang sulit mengingat sebagian besar orang hanya memiliki dua orang anak dan kemungkinan yang memiliki anak laki-laki sedikit, jikapun ada orangtua yang memiliki anak laki-laki lebih dari satu, namun kemungkinan besar orangtua itu tidak mengijinkan anaknya untuk melakukan perkawinan nyentana.

Pikiran yang muncul ketika anak sudah semakin besar, membuat orangtua harus lebih memikirkan kedepannya terkait penerus garis keturunan. Berbeda ketika anaknya masih kecil, hal tersebut masih bisa dihindari untuk dipikirkan, namun ketika anaknya sudah semakin besar, hal itu sudah menjadi sesuatu yang serius dan tidak bisa lagi diandai-andaikan saja.

Masyarakat juga memiliki pengaruh terhadap keadaan orangtua, pertanyaan-pertanyaan yang muncul dari masyarakat terkait hanya memiliki anak perempuan memengaruhi kondisi orangtua. Melihat orang lain yang sama-sama hanya memiliki anak perempuan dan sudah mendapatkan sentana membuat orangtua yang hanya memiliki anak perempuan semakin terganggu, karena menganggap bahwa orang lain begitu mudah mendapatkan sentana, sedangkan diri individu sendiri merasa sulit.

Faktor yang menurunkan kecemasan

Terdapat faktor yang meningkatkan kecemasan orangtua, ada beberapa faktor yang dapat menurunkan kecemasan yang dirasakan oleh orangtua yang hanya memiliki anak perempuan. Pertama yang dipikirkan oleh orangtua yaitu mendapat sentana. Nyentana adalah alternatif utama bagi orangtua yang hanya memiliki anak perempuan untuk meneruskan garis keturunannya, nyentana berarti garis keturunan anak akan mengikuti garis ibunya. Hal tersebut berarti bahwa, orangtua yang hanya memiliki anak perempuan dapat meneruskan gais keturunannya. Selain nyentana, terdapat alternatif lain yang dilakukan orangtua yang hanya memiliki anak perempuan, yaitu melakukan perkawinan Pada gelahang. Individu yang melakukan perkawinan Pada 
gelahang akan memiliki tanggung jawab yang sama dikedua belah pihak keluarga yaitu keluarga laki-laki dan perempuan. Meras anak juga dijadikan sebagai alternatif bagi orangtua yang hanya memiliki anak perempuan dalam memperoleh keturunan. Memeras anak yaitu mengangkat salah satu cucu dari orangtua yang hanya memiliki anak perempuan sebagai anaknya.

Pengalaman-pengalaman dari orang sekitar ataupun teman memberikan pandangan yang lebih luas terkait dengan kondisi individu itu sendiri. Ditambah dengan pikiran bahwa sudah memiliki saudara untuk meneruskan keturunan dapat menurukan kecemasan pada orangtua yang hanya memiliki anak perempuan. Kepercayaan orangtua pada anak juga memengaruhi dalam menurunkan kecemasan, yaitu kepercayaan bahwa suatu saat anak akan memiliki inisiatif sendiri untuk memperoleh laki-laki yang mau diajak nyentana. Usia yang semakin bertambah memengaruhi cara pandang individu terhadap kondisi yang dialami semakin bijaksana. Kepercayaan bahwa apabila nantinya sudah tidak ada yang mengurus dihari tua karena anak semua menikah keluar, individu percaya bahwa masyarakat tidak akan tinggal diam apabila terjadi sesuatu yang tidak diinginkan. Kondisi individu tidak menyurutkan niatnya untuk tetap berdoa dan percaya bahwa suatu sata anak perempuannya akan mendapatkan pasangan yang mau nyentana.

Individu juga meyakini bahwa apa yang menjadi kondisi individu saat ini adalah hasil dari perbuatan individu terdahulu atau karma, dan individu percaya apapun yang akan terjadi nantinya merupakan sudah ada yang mengatur atau sudah menjadi takdir dari individu itu sendiri.

\section{Upaya yang Dilakukan Orangtua yang Hanya Memiliki Anak Perempuan}

(Bagan 4. Upaya yang dilakukan orangtua yang hanya memiliki anak perempuan. Terlampir) Kondisi yang dialami oleh orangtua yang hanya memiliki anak perempuan tentu saja akan menimbulkan suatu kecemasan, sehingga orangtua melakukan beberapa upaya untuk menghindari diri dari kecemasan tersebut. Orangtua meminta pada anak perempuannya agar dapat mencari pasangan yang nantinya mau untuk diajak nyentana. Hal tersebut dilakukan sebagai usaha orangtua untuk memperoleh garis keturunan, sehingga tidak mengalami kaputungan.

Orangtua juga akan lebih protective terhadap anaknya baik membatasi anak dalam berpacaran dengan laki-laki yang tidak bisa nyentana dan melarang anak cepat-cepat menikah serta membatasi anak untuk keluar.

\section{PEMBAHASAN DAN KESIMPULAN}

Berdasarkan hasil penelitian yang telah dilakukan, maka diperoleh hasil terkait gambaran kecemasan orangtua yang hanya memiliki anak perempuan. Gambaran kecemasan orangtua terdiri dari empat kategori yaitu emosi orangtua, bentuk kecemasan, faktor yang memengaruhi kecemasan dan upaya yang dilakukan orangtua yang hanya memiliki anak perempuan.

\section{Emosi Orangtua yang Hanya Memiliki Anak Perempuan} Setiap orangtua akan menunjukkan suatu emosi ketika memiliki anak, karena anak adalah sebuah anugrah yang dititipkan ketika kita sudah menikah. Pentingnya anak bagi masyarakat Bali adalah sebuah keturunan yang nantinya dapat meneruskan tanggung jawab orangtua dan leluhurnya, sehingga bagi orangtua atau pasangan suami istri memperoleh anak adalah hal yang utama dalam perkawinan. Baik pria dan wanita akan memiliki perasaan bercampur aduk saat menjadi orangtua, bersama dengan kegairahan, orangtua mungkin merasakan kecemasan akan tanggung jawab membesarkan anak dan komitmen waktu serta energi yang dituntut (Papalia, Old, \& Feldman, 2011). Hal itu sejalan dengan hasil yang diperoleh pada penelitian kali ini, yaitu emosi yang muncul bagi orangtua yang hanya memiliki anak perempuan cukup berbeda, dari hasil wawancara terhadap responden bahwa emosi yang muncul ketika hanya memiliki anak perempuan dapat digolongkan kedalam dua kategori yaitu emosi positif dan negatif.

Emosi positif cenderung seperti bahagia, bahagia, menerima, bersyukur, santai, ikhlas dan pasrah. Emosi negatif yang muncul yaitu rasa kecewa, takut, lebih waspada, iri melihat orang lain, berpikir keras dan was-was. Emosi positif yang muncul dikarenakan perasaan alamiah individu sebagai orangtua, yang memiliki anak sebagai buah hatinya. Emosi negatif muncul pada orangtua yang hanya memiliki anak perempuan berkaitan dengan kecemasan yang muncul terkait tanggung jawab dalam membesarkan anak dan beban lain yang dirasakan oleh orangtua. Beban yang dimaksudkan adalah terkait penerus atau pewaris untuk meneruskan garis keturunan responden didalam keluarganya. Di Bali sendiri menganut sistem kekeluargaan patrilineal, yaitu garis keturunan mengikuti garis ayah. Berarti sangat penting bagi setiap pasangan suami istri untuk memiliki anak laki-laki sebagai penerus garis keturunan, selain itu terksit dengan tanggung jawab yang harus diteruskan baik berupa kewajiban (swadharma) dan hak-hak (swadikara) seseorang dalam keluarga serta masyarakat (desa pakraman atau banjar).

\section{Bentuk Kecemasan Orangtua}

Berdasarkan hasil yang diperoleh, orangtua yang hanya memiliki anak perempuan di daerah Tabanan Bali cenderung merasa cemas, mengingat garis keturunan di Bali jatuh pada garis keturunan ayah atau laki-laki, sehingga orangtua yang hanya memiliki anak perempuan tentu memiliki kendala dalam meneruskan garis keturunan. Adapun bentuk kecemasan yang muncul berdasarkan ciri-ciri kecemasan yang dikemukakan oleh Nevid et al. (2005) terdiri dari 3 ciri yaitu ciri fisik, ciri kognitif dan ciri behavioral. Adapun yang termasuk kedalam ciri fisik yaitu sulit tidur dan sakit perut, sedangkan yang termasuk ke dalam ciri kognitif yaitu melamun dan cepat marah, terakhir yang termasuk ke dalam ciri behavioral yaitu menangis. Sejalan dengan hal tersebut, menurut Freud (dalam Feist \& Feist, 2013) menjelaskan bahwa kecemasan merupakan situasi afektif yang dirasa tidak menyenangkan yang diikuti oleh sensasi fisik yang memperingatkan seseorang akan bahaya yang mengancam. Kali ini, kecemasan yang dirasakan responden hingga 
terkadang bereaksi pada fisik responden, salah satu responden merasa sakit perut jika terus memikirkan keadaannya. Responden juga sering menangis dan lebih sensitif sehingga terkadang membuat responden cepat marah. Memikirkan keadaan yang dialami responden juga membuat responden kesulitan dalam tidur, melamun dan sering menangis, seperti yang dinyatakan oleh (King, 2010) bahwa gangguan kecemasan juga dapat diartikan sebagai gangguan psikologis, meliputi ketegangan motorik (bergetar, tidak mampu duduk tenang, tidak mampu bersantai); hiperaktivitas (pusing, jantung yang berdetak cepat dan berkeringat); serta harapanharapan yang dirasakan dan pikiran mendalam yang dialami oleh individu.

\section{Faktor yang Memengaruhi Kecemasan}

Terdapat beberapa faktor yang memengaruhi munculnya suatu kecemasan pada diri responden. Faktor-faktor tersebut dibagi dalam dua kategori yaitu faktor yang meningkatkan kecemasan, dan faktor yang menurunkan kecemasan. Adapun faktor yang memicu munculnya kecemasan pada orangtua yang hanya memiliki anak perempuan yaitu keturunan atau pewaris, putung, memikirkan keadaan dihari tua jika ditinggal anak, susah mencari sentana, ketika anak semakin besar dan adanya pengaruh dari masyarakat.

Setiap individu yang melakukan pernikahan tentu saja akan mengharapkan sebuah keturunan untuk meneruskan tanggung jawab orangtua dan leluhurnya. Berdasarkan sistem kekeluargaan patrilineal yang dianut di Bali yaitu garis keturunan mengikuti garis kapurusa (ayah). Artinya, untuk meneruskan garis keturunan individu haruslah memiliki anak laki-laki. Sementara bagi individu yang tidak memiliki anak laki-laki atau hanya memiliki anak perempuan tentunya memiliki kendala dalam meneruskan garis keturunan. Seperti yang dinyatakan oleh Windia et al. (2014) bahwa, kedudukan anak atau keturunan sangat penting, karena terkait dengan penerusan tanggung jawab orangtua dan leluhur, baik berupa kewajiban (swadharma) maupun hak (swadikara), sehingga keturunan dianggap responden sebagai faktor yang dapat meningkatkan kecemasan responden. Pikiran yang muncul selain tidak memiliki anak laki-laki, yaitu mengenai penerus garis keturunan menjadi alasan meningkatnya kecemasan responden. Ketika tidak ada yang meneruskan garis keturunan pada sebuah keluarga, maka keluarga itu akan dinyatakan putung (putusnya garis keturunan). Tentu saja tidak ada individu yang ingin jika keturunannya terhenti atau tidak ada yang meneruskan garis keturunan.

Ketakutan responden mengenai hari tua jika ditinggal oleh anaknya merupakan faktor yang memicu meningkatnya kecemasan, menurut Papalia, Old, \& Feldman (2011) orang dewasa yang lebih tua menjadi lebih pendek seiring dengan melemahnya tulang vertebrae, komposisi kimia tulang juga berubah, menciptakan risiko keretakan yang lebih besar. Perubahan juga terjadi pada sistem organ tubuh lainnya terjadi pada fungsi otak, sensoris, motoris dan fungsi seksual. Menurunnya fungsi tubuh orang dewasa yang lebih tua mengakibatkan individu yang hanya memiliki anak perempuan takut jika ditinggalkan oleh anaknya.
Responden juga mengatakan bahwa responden semakin takut ketika anaknya mulai besar dan sudah mulai tertarik dengan lawan jenis. Menurut Santrock (2007) perubahan psikososial pada fase remaja akhir ditandai dengan lebih memperhatikan masa depan, termasuk peran yang diinginkan nantinya. Remaja akhir mulai serius dalam berhubungan dengan lawan jenis, dan mulai dapat menerima tradisi dan kebiasaan lingkungan. Hal tersebut sejalan dengan yang ditakutkan oleh responden, ketika anak sudah mulai tertarik pada lawan jenis menuntut orangtua lebih meningkatkan pengawasannya.

Masyarakat juga menjadi salah satu faktor yang meningkatkan kecemasan orangtua yang hanya memiliki anak perempuan. Pertanyaan-pertanyaan yang muncul dari masyarakat terkait keadaan tentu saja semakin mengingatkan responden akan ketakutannya. Melihat keadaan dalam masyarakat yang memiliki kondisi yang sama terhadap responden dan sudah mendapatkan sentana sebagai penerus garis keturunannya akan meningkatkan kecemasan responden. Sejalan dengan penelitian yang dilakukan oleh Ramaiah (2003) lingkungan sebagai salah satu faktor yang dapat menunjukkan reaksi kecemasan, dikarenakan lingkungan atau sekitar tempat tinggal memengaruhi cara berpikir individu tentang diri sendiri maupun orang lain. Hal ini disebabkan karena adanya pengalaman yang tidak menyenangkan pada individu dengan keluarga, sahabat, ataupun dengan rekan kerja, sehingga individu tersebut merasa tidak aman terhadap lingkungannya.

Adapun faktor yang dianggap menurunkan kecemasan orangtua yang hanya memiliki anak perempuan diantaranya yaitu nyentana, Pada gelahang, meras anak, meremug dengan warang, Sharing, kodrat wanita menikah keluar. Di Bali menganut sistem kekeluargaan patrilineal yaitu keturunan mengikuti garis ayah (kapurusa). Hal tersebut berarti, garis keturunan dapat diteruskan apabila memiliki anak laki-laki sebagai penerus (Sukerti, 2012). Orangtua yang hanya memiliki anak perempuan tentu mengalami kendala dalam meneruskan garis keturunannya, sehingga untuk menghindari kaputungan bagi orangtua yang hanya memiliki anak perempuan akan melakukan alternatif lain untuk meneruskan garis keturunan yaitu melalui perkawinan nyentana atau Pada gelahang. Perkawinan nyentana yaitu keturunan mengikuti garis ibu, karena ibu yang berkedudukan sebagai purusa, sedangkan pada perkawinan Pada gelahang, tanggung jawab yang dilaksanakan oleh suami istri yang menjalankan perkawinan Pada gelahang harus seimbang terhadap keluarga baik keluarga suami atau istri karena sama-sama berkedudukan sebagai purusa.

Responden yang hanya memiliki anak perempuan meminta kepada anak perempuannya untuk mencari laki-laki yang mau nyentana, dan jika tidak ada laki-laki yang bersedia nyentana maka jalan lain yang dilakukan yaitu melalui perkawinan Pada gelahang. Sejalan dengan apa yang dinyatakan oleh Windia et al. (2014) bahwa bagi pasangan suami istri yang hanya dikaruniai anak perempuan saja, akan mengusahakan salah seorang anak perempuannya untuk tinggal di rumah dan berusaha menemukan laki-laki yang bersedia melangsungkan perkawinan nyentana. Apabila dalam keadaan tertentu tidak ada laki-laki yang bersedia melangsungkan perkawinan 
nyentana, karena kebetulan laki-laki adalah anak tunggal dalam keluarganya atau karena sebab lain, maka untuk menghindari kaputungan maka atas kesepakatan calon pengantin dan keluarga masing-masing, diusahakan dengan melangsungkan perkawinan Pada gelahang.

Responden juga mengatakan bahwa alternatif lain yang akan dilakukan apabila anak perempuannya tidak mendapatkan laki-laki yang mau nyentana yaitu dengan meras anak, responden akan mengangkat cucunya sebagai anak dan melalui proses banten pamerasan. Responden juga mengatakan bahwa, perlu adanya komunikasi antara kedua belah pihak sebelum memutuskan jalan tengah bagi kedua belah pihak. Sejalan dengan yang dinyatakan oleh Windia (2014) mengangkat anak berkaitan dengan masalah penerus keturunan. Pengangkatan anak dimulai dari remug keluarga, kemudian disiarkan dalam satu sangkepan banjar, tujuannya untuk mengetahui lebih jauh apabila ada keluarga yang keberat. Apabila tidak ada yang menyatakan keberatan, maka akan dilanjutkan dengan upacara pamerasan dan setelah itu dilanjutkan dengan penyelesaian administrasi.

Dukungan sosial adalah dukungan secara emosional maupun berupa informasi-informasi yang mendukung, rasa peduli dan empati, pemberian umpan balik yang positif, dan kesediaan meluangkan waktu dan tenaga sebagai bentuk pelayanan atau saling menyayangi (Compton, 2005). Responden menyatakan bahwa, saling bertukar pikiran dengan teman atau orang-orang disekitar yang memiliki situasi yang sama dengan responden dapat memberikan wawasan yang lebih luas bagi responden, hal tersebut memberikan responden banyak pengalamanpengalaman orang lain yang dapat dijadikan pedoman sehingga responden tidak melihat masalah hanya dari sudut pandang diri sendiri. Hal tersebut sejalan dengan yang dikemukakan oleh Taylor (2009) bahwa dukungan sosial adalah dukungan atau informasi-informasi yang diperoleh dari orang-orang dekat atau komunitas yang saling peduli dan menyayangi satu sama lain.

Sistem kekeluargaan patrilineal yang dianut di Bali yang berarti mengikuti garis keturunan ayah, dengan kata lain proses perkawinan mengikuti laki-laki (Sukerti, 2012). Hal tersebut tertanam pada masyarakat bahwa anak laki-laki tetap tinggal di rumah orangtuanya dan meneruskan garis keturunan keluarga, sedangkan anak perempuan pergi keluar atau menikah mengikuti yang laki-laki. Responden berpikir bahwa memang sudah menjadi kodrat seorang wanita menikah keluar.

\section{Upaya yang Dilakukan Orangtua}

Bagi orangtua yang hanya memiliki anak perempuan akan mengupayakan berbagai cara yang dilakukan untuk mengatasi keadaannya, seperti yang telah dilakukan responden yaitu dengan meminta anak perempuannya untuk mencari sentana, ketika anak perempuannya mendapatkan laki-laki yang bisa nyentana, maka bagi responden yang hanya memiliki anak perempuan dapat meneruskan garis keturunannya. Sejalan dengan yang dinyatakan oleh Windia et al. (2014) bagi pasangan suami istri yang hanya dikaruniai anak perempuan saja akan mengusahakan anak perempuannya untuk tinggal di rumah dan mencari laki-laki yang bersedia melakukan perkawinan nyentana.

Orangtua yang hanya memiliki anak perempuan cenderung akan lebih overprotective pada anaknya. Seperti yang dilakukan salah satu responden, responden membatasi anaknya untuk berpacaran dengan sembarang laki-laki, atau tidak mengijinkan anaknya untuk berpacaran dengan laki-laki yang tidak bisa nyentana, selain itu responden cenderung melarang anak perempuannya untuk cepat-cepat menikah. Hal ini sejalan dengan yang dinyatakan oleh Antonucci et al., (dalam Papalia et al., 2011) ketika anak-anak mulai meninggalkan rumah untuk menikah atau sering disebut dengan empty nest, akan lebih sulit dilalui oleh pasangan yang identitasnya tergantung pada peran parental, atau yang sekarang harus menghadapi masalah perkawinan yang sebelumnya dikesampingkan karena berada dibawah tekanan tanggung jawab sebagai orangtua. Hal itu dilakukan orangtua sebagai upaya untuk menunda kekosongan atau kesepian yang nantinya dialami responden dikarenakan ditinggal oleh anaknya menikah.

Terdapat sejumlah saran dalam penelitian ini. Saran kepada para orangtua yang hanya memiliki anak perempuan, disarankan untuk lebih banyak mencari tahu pengalamanpengalaman orang lain yang memiliki kondisi yang sama sehingga mendapatkan wawasan yang lebih luas terkait kondisi yang dialami. Sharing dengan teman atau orang-orang disekitar juga dapat dilakukan untuk saling bertukar pikiran sehingga orangtua yang hanya memiliki anak perempuan dapat menemukan alternatif-alternatif lain untuk meneruskan garis keturunan selain melalui nyentana.

Kepada anak sangat disarankan untuk saling mengerti keadaan yang dirasakan oleh orangtua sehingga baik bagi orangtua maupun anak dapat saling mengisi satu sama lain. Disarankan pula untuk anak agar dapat menjadi bagian dari tempat orangtua berbagi perasaan dan lebih mendekatkan diri kepada orangtua sehingga nantinya anak dapat memahami apa yang dirasakan oleh orangtuanya, sehingga orangtua merasa tetap mendapatkan dukungan dari anak.

Kepada masyarakat yang tidak memiliki kondisi yang sama, hendaknya dapat saling menjaga perasaan satu sama lain dan dapat memberikan support bagi orangtua yang hanya memiliki anak perempuan. Selain itu, disarankan kepada masyarakat agar lebih memperhatikan kata-kata ataupun sikap yang tanpa disadari dapat menyinggung perasaan orangtua yang hanya memiliki anak perempuan.

Kepada peneliti selanjutnya, disarankan untuk dapat memperdalam penelitian terkait fenomena apa saja yang dialami secara kultural oleh orangtua yang hanya memiliki anak perempuan. Disarankan pula untuk memperdalam penelitian terkait fenomena yang dirasakan dari perkawinan nyentana, yang dilihat dari sudut pandang anak perempuan itu sendiri, sehingga pada nantinya ditemukan hasil penelitian yang dapat diaplikasikan pada pihak anak maupun orangtua. 


\section{DAFTAR PUSTAKA}

Artadi, I. K. (2007). Hukum adat Bali dengan aneka masalahnya. Denpasar: Pustaka Bali Post.

Atkinson, R. L., Atkinson, R. C., \& Hilgard, E. R. (1983). Pengantar psikologi I. Jakarta: Erlangga.

Atmaja, J. (2008). Bias gender perkawinan terlarang pada masyarakat Bali. Denpasar: Udayana University Press.

Brannon, L. (2011). Gender : Psychological perspectives sixth edition. USA: Pearson.

Compton, W. C. (2005). Introduction to positive psychology. Belmont, USA: Thomson Wadswort.

Daradjat, Z. (1983). Kesehatan mental. Jakarta: Gunung Agung.

Davidson, G. C., Neale, J. M., \& Kring, A. M. (2004). Psikologi abnormal. Jakarta: PT. RajaGrafindo Persada.

DSM IV-TR. (2000). Diagnostic and statistical manual of mental disorders (DSM IV-TR). Washington DC: American Psychiatric Association.

Duvall, E. M., \& Miller, B. C. (1985). Marriage and development, 6th ed. USA: Hurper \& Row Publisher, Inc.

Dyatmikawati, P. (2011). Perkawinan pada gelahang dalam masyarakat hukum adat di provinsi Bali ditinjau dari undang-undangg no. 1 tahun 1974 tentang perkawinan. DIH, Jurnal Hukum Vol. 7, No. 14, 111-122.

Feist, J., \& Feist, G. J. (2013). Teori kepribadian edisi 7. Jakarta: Salemba Humanika.

Herdiansyah, H. (2016). Gender dalam perspektif psikologi. Jakarta: Salemba Humanika.

Hurlock, E. (2000). Psikologi perkembangan : Suatu Pendekatan Sepanjang Rentang Kehidupan. Jakarta: Erlangga.

Irwin, D. M., \& Bushnell, M. M. (1980). Observational strategies for child study. United States of America: Holt, Rinehart and Winston.

King, L. (2010). Psikologi umum sebuah pandangan apresiatif. Salemba Humanika.

Maramis. (2009). Catatan ilmu kedokteran jiwa. Surabaya: Airlangga.

Mariyam, A. K. (2008). Faktor-faktor yang berhubungan dengan tingkat kecemasan orangtua terkait hospitalisasi anak usia toddler di BRSD RAA Soewonso Pati. Jurnal Keperawatan , 38-59.

Moleong, L. (2014). Metode penelitian kualitatif. Bandung: PT. Remaja Rosdakarya.

Monika, K. A. (2016). Pandangan orangtua yang hanya memiliki anak perempuan terkait sistem perkawinan di daerah Tabanan. Studi Pendahuluan .

Muhammad, A. (2000). Hukum perdata di Indonesia. Bandung: PT. Citra Aditya Bakti.

Nevid, J. S., \& Greene, B. (2005). Abnormal psychology in a changing world $(5$ ed). (T. f. udaya, penerj). Jakarta: Erlangga.

Nugraha, K. A. (2014). Pelaksanaan pembagian warisan pada perkawinan pada gelahang Menurut Hukum Adat Bali (Studi di Kabupaten Tabanan). 1-14.

Olson, D., \& DeFrain, J. (2003). Marriage and families: intimacy, diversity, and strenghts fourth edition. New York: McGraw-Hill Higher Education.

Papalia, D. E., Old, S. W., \& Feldman, R. D. (2011). Edisi kesembilan human development (psikologi perkembangan). Jakarta: Kencana.

Pursika, I. N., \& Arini, N. W. (2012). Pada gelahang: suatu perkawinan alternatif dalam mendobrak kekuatan budaya patriaki di Bali. Jurnal Ilmu Sosial dan Humonaria Vol 1 No 2, Oktober 2012, 75.

Raditya P., I. P., Rato, D., \& Zulaika, E. (2014). Hak waris anak perempuan terhadap harta guna karya orangtuanya menurut hukum adat waris Bali.
Ramaiah, D. S. (2003). Kecemasan bagaimana mengatasi penyebabnya. Jakarta: Pustaka Populer Obor.

Rufaidhah, E. R. (2009). Efektifitas terapi kognitif perilaku terhadap penurunan tingkat kecerdasan pada penderita asma. Tesis. Universitas Gajah Mada .

Santrock, J. W. (2007). Remaja, edisi kesebelas. Jakarta: Penerbit Erlangga.

Soekanto, S. (2005). Sosiologi suatu pengantar. Jakarta: PT. RajaGrafindo Persada.

Suastika, I. N. (2010). Nyentana arus balik patrilinial (studi kasus status, kedudukan dan peranan perempuan putrika setelah perceraian pada masyarakat Bali aga di kabupaten Bangli).

Sugiyono. (2015). Metode penelitian kombinasi (Mix Method). Bandung: Alfabeta.

Sukerti, N. N. (2012). Hak mewaris perempuan dalam hukum adat Bali sebuah studi kritis. Denpasar: Udayana University Press.

Susan, D. R. (2012). Kecemasan ibu menghadapi anak sulung pada usia remaja.

Taylor, S. E. (2009). Health psychology. New York: McGraw-Hill Companies, Inc.

Teknik keluarga berencana. (1980). Bandung: Elstar Offset.

Windia, W. P. (2014). Hukum adat Bali. Denpasar: Udayana University Press.

Windia, W. P., Sudantara, I. K., Komalasari, G. A., Suartika, I. G., Dyatmikawati, P., Pemayun, C. I., et al. (2009). Perkawinan pada gelahang di Bali. Denpasar: Udayana University Press.

Windia, W. P., Sudantra, I. K., Komalasari, G. A., Suartika, I. G., Dyatmikawati, P., Pemayun, C. I., et al. (2014). Perkawinan pada gelahang di Bali. Denpasar: Udayana University Press. 


\section{LAMPIRAN}

Tabel 1

Karakteristik Responden Penelitian

\begin{tabular}{|c|c|c|c|c|c|c|c|c|c|}
\hline No. & $\begin{array}{c}\text { Kode } \\
\text { responden }\end{array}$ & $\begin{array}{c}\text { Jenis } \\
\text { kelamin } \\
(\mathbf{L} / \mathbf{P})\end{array}$ & Usia & Pekerjaan & $\begin{array}{c}\text { Peran } \\
\text { keluarga } \\
\text { besar }\end{array}$ & $\begin{array}{c}\text { Memiliki } \\
\text { alternatif } \\
\text { lain }\end{array}$ & $\begin{array}{c}\text { Jumlah } \\
\text { anak }\end{array}$ & $\begin{array}{c}\text { Kendala dalam } \\
\text { memperoleh anak }\end{array}$ & $\begin{array}{l}\text { Pengaman pribadi } \\
\text { responden }\end{array}$ \\
\hline 1. & $\mathrm{WN}$ & L & 52 tahun & Wiraswasta & $\begin{array}{l}\text { Tidak } \\
\text { mendukung }\end{array}$ & Memiliki & 2 & $\begin{array}{l}\text { Susah ketika } \\
\text { melahirkan, } \\
\text { sehingga tidak } \\
\text { berkeinginan } \\
\text { memiliki anak } \\
\text { kembali, walaupun } \\
\text { anaknya hanya } \\
\text { perempuan. }\end{array}$ & - \\
\hline 2. & TA & L & 49 tahun & Dosen & Mendukung & Memiliki & 1 & $\begin{array}{l}\text { Keguguran } \\
\text { sebanyak dua kali, } \\
\text { sehingga menerima } \\
\text { anak yang dimiliki } \\
\text { perempuan, dan } \\
\text { sudah ada usaha } \\
\text { untuk memiliki } \\
\text { anak kembali, } \\
\text { namun tidak } \\
\text { membuahkan hasil. }\end{array}$ & - \\
\hline 3. & SK & $\mathrm{L}$ & 49 tahun & $\begin{array}{c}\text { Buruh } \\
\text { bangunan }\end{array}$ & Mendukung & $\begin{array}{l}\text { Tidak } \\
\text { memiliki }\end{array}$ & 2 & $\begin{array}{l}\text { Kendala terkait } \\
\text { ekonomi, sehingga } \\
\text { memiliki dua anak } \\
\text { culup, walaupun } \\
\text { jenis kelamin anak } \\
\text { perempuan. }\end{array}$ & - \\
\hline
\end{tabular}

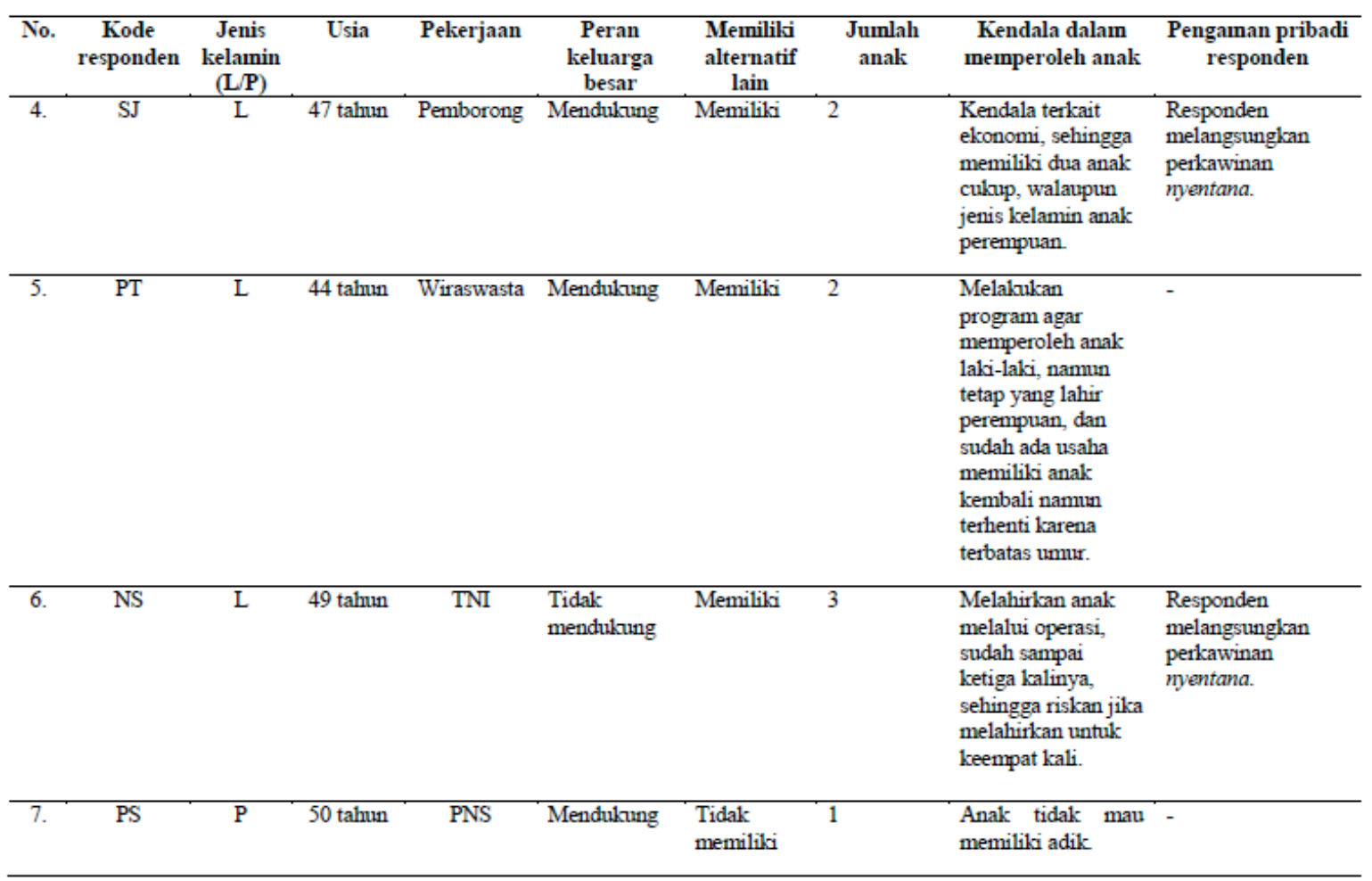




\section{Bagan 1}

Emosi orangtua yang hanya memiliki anak perempuan

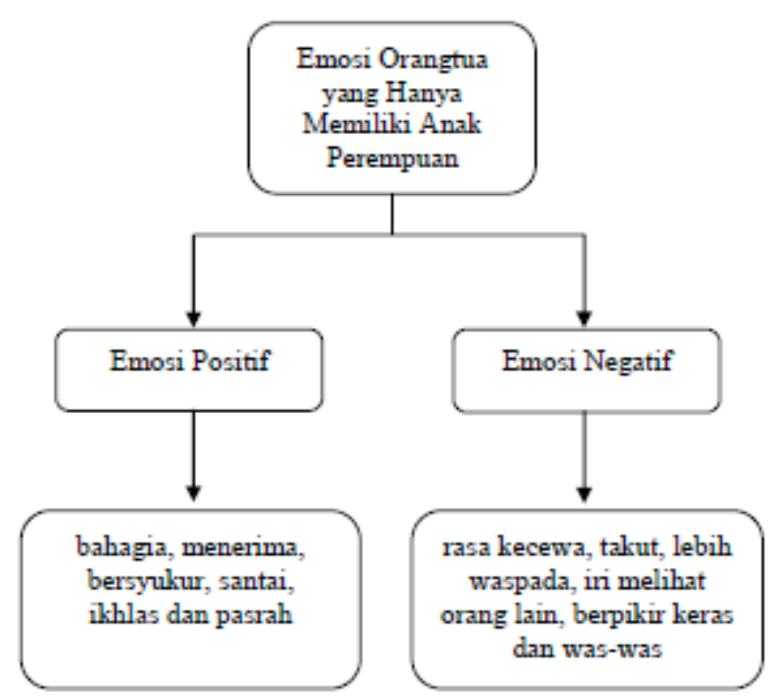




\section{Bagan 2}

Bentuk kecemasan orangtua yang hanya memiliki anak perempuan

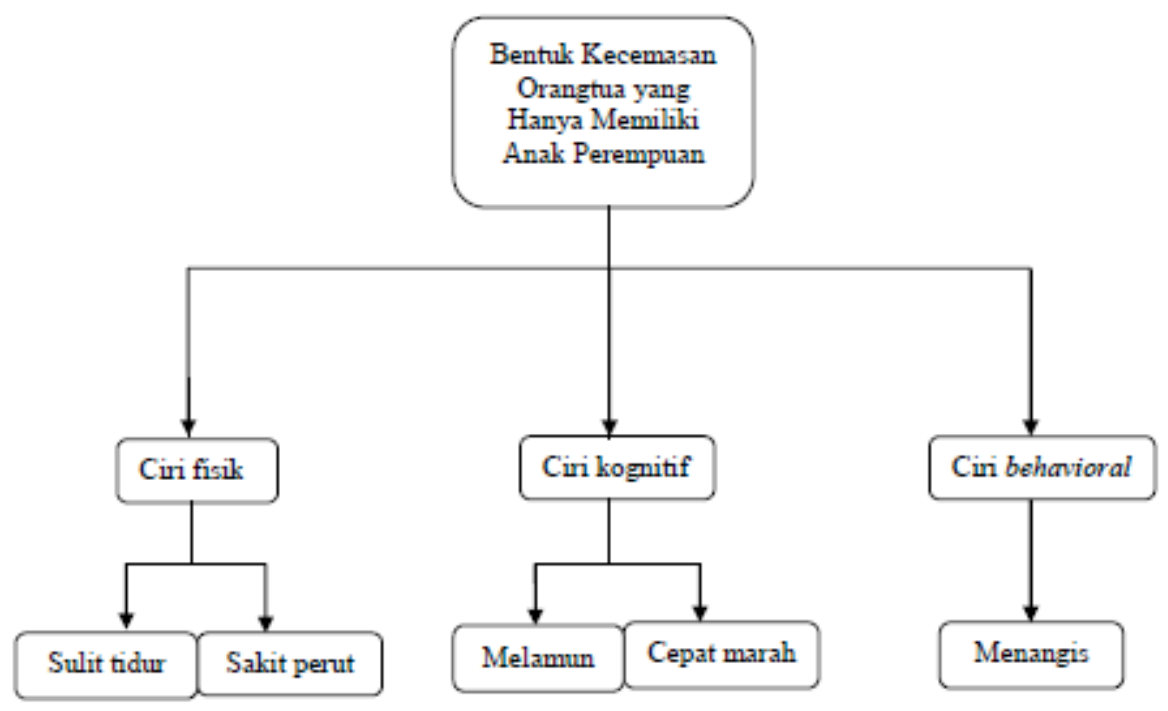




\section{Bagan 3}

Faktor yang Memengaruhi Kecemasan Orangtua

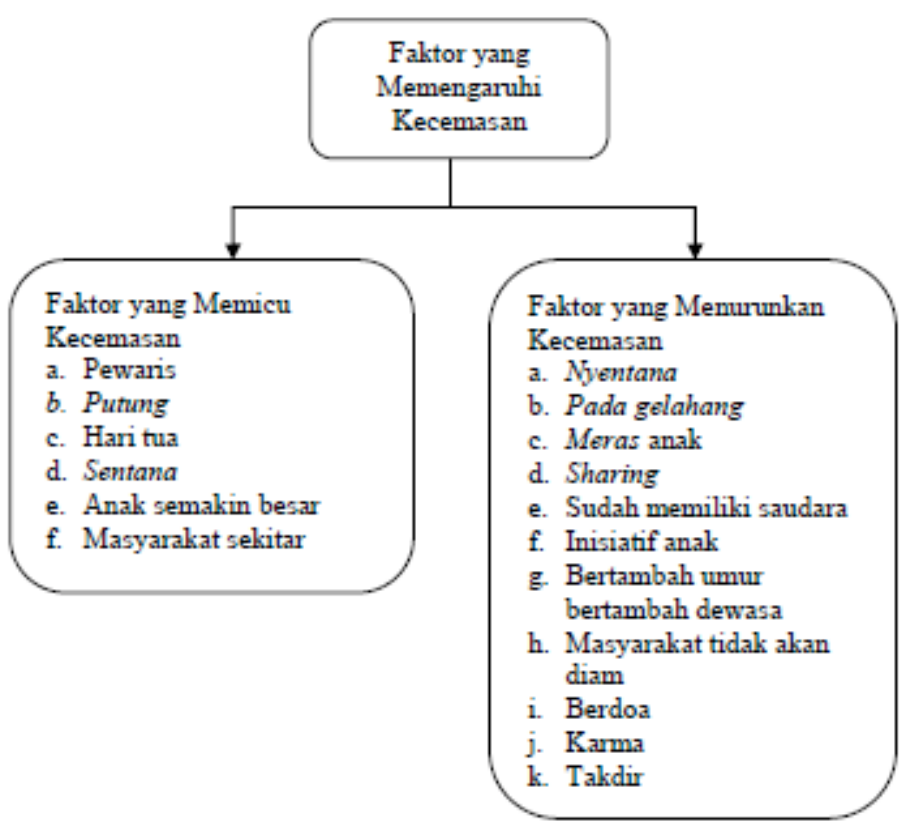


K. A. MONIKA \& D. H. TOBING

\section{Bagan 4}

Upaya yang dilakukan orangtua yang hanya memiliki anak perempuan

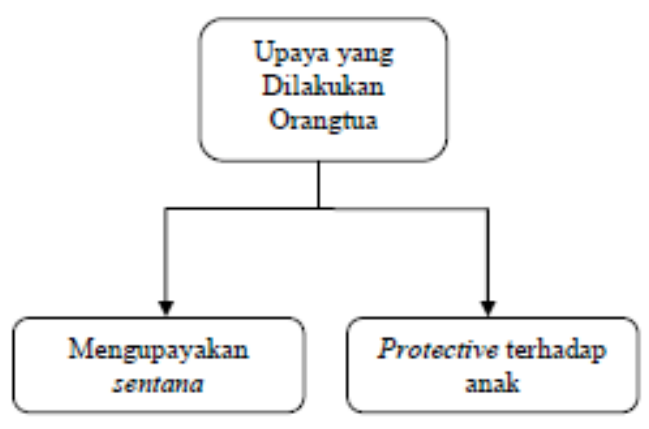

